\title{
ANALISIS KEINTEGRASIAN MUATAN PELAJARAN SEKOLAH DASAR KELAS I TEMA BENDA, HEWAN DAN TANAMAN DI SEKITARKU
}

\author{
L. Ermayani ${ }^{1}$, N. Dantes ${ }^{2}$, A.A.I.N. Marhaeni ${ }^{3}$ \\ ${ }^{123}$ Program Studi Pendidikan Dasar \\ UniversitasPendidikan Ganesha \\ Singaraja, Indonesia \\ e-mail: ermayaniluh96@gmail.com ${ }^{1}$, dantes@undiksha.ac.id ${ }^{2}$, \\ ngr.marhaeni@undiksha.ac.id ${ }^{3}$
}

\begin{abstract}
Abstrak
Penelitian ini bertujuan untuk mengetahui dan mendeskripsikan keintegrasian pada materi pembelajaran, rancangan langkah-langkah kegiatan pembelajaran, rancangan penilaian, rancangan media dan sumber belajar Sekolah Dasar kelas I tema Benda, hewan dan Tanaman di Sekitarku. Penelitian ini merupakan penelitian deskriptif kualitatif.Teknik pengumpulan data yang digunakan adalah metode dokumentasi. Analisis data yang digunakan yaitu pengumpulan data, reduksi data, penyajian data, dan penarikan kesimpulan. Berdasarkan analisis data, diperoleh hasil penelitian bahwa: 1) terdapat keintegrasian pada materi pembelajaran sebesar $91,07 \%$ kategori sangat baik yang cenderung pada klasifikasi integrasi intradisipliner. 2) terdapat keintegrasian pada rancangan langkah-langkah kegiatan pembelajaran sebesar 92,31\% kategori sangat baik yang cenderung pada klasifikasi integrasi intradisipliner, 3) terdapat keintegrasian pada rancangan penilaian sebesar $85,13 \%$ kategori baik yang cenderung pada klasifikasi integrasi intradisipliner, 4) terdapat keintegrasian pada rancangan media dan sumber belajar sebesar $83,33 \%$ kategori baik yang cenderung pada klasifikasi integrasi intradisipliner. Adanya keintegrasian pada keempat komponen pembelajaran menunjukkan buku guru dan buku siswa baik diimplementasikan di Sekolah Dasar.
\end{abstract}

Kata Kunci : Keintegrasian; Kurikulum 2013

\section{Abstract}

This study aims to investigate and describe the integration of learning materials, the design of learning activities steps, assessment design, the design of media, and learning resources of grade I Elementary School with themes of objects, animals, and plants around me. This research was qualitative descriptive research. The data collection technique was the documentation method. The data analysis was data collection, data reduction, data display, and conclusion. Based on the data analysis, the results of the study showed that: 1) there was integration in the learning material of $91,07 \%$ was categorized as excellent which tends to the classification of intradisciplinary integration. 2) there was integration in the learning activities steps design $92,31 \%$ was categorized very good that tend to the classification of intradisciplinary integration, 3) there was integration in the assessment design $85,13 \%$ was categorized well which tend to the classification of intradisciplinary integration, 4) there was integration in media design and learning resources $83,33 \%$ was categorized good which tend to the classification of intradisciplinary integration. The integration in the four learning components showed that teacher and student books were good to be implemented in Elementary School.

Keywords : Integration; Curriculum 2013

\section{PENDAHULUAN}

Pengembangan Kurikulum menjadi salah satu upaya pemerintah untuk menciptakan pendidikan yang berkualitas. Mengingat pentingnya kurikulum dalam pendidikan dan kehidupan manusia, maka penyusunan kurikulum dilakukan untuk mewujudkan proses berkembangnya kualitas potensi peserta didik. Kurikulum yang pernah digunakan yaitu mulai dari Kurikulum Berbasis Kompetensi (KBK), Kurikulum Tingkat Satuan Pendidikan 
(KTSP) dan yang terbaru Kurikulum 2013. Pembaharuan kurikulum diharapkan mampu mengubah pola pembelajaran yang awalnya berpusat pada guru (teacher centered) menjadi berpusat pada siswa (student centered). Penerapan kurikulum 2013 menjadi tantangan sekaligus peluang bagi tenaga pendidik yang menjadi garda terdepan demi mewujudkan cita-cita pendidikan. Namun tentu saja semua itu tergantung oleh dukungan masyarakat dan khususnya pelaku pendidikan itu sendiri seperti guru dan kepala sekolah dan juga peserta didik serta orang tua peserta didik. Banyak hal yang menjadi kendala yang menjadi bagian dari penerapan Kurikulum 2013 salah satunya adalah kesiapan guru mengemas pembelajaran sesuai dengan prosedur kurikulum baik dalam pemaparan materi sesuai tema, dengan tema, rancangan pembelajaran, penilaian serta penggunaan media pembelajaran sebagai pendukung proses pembelajaran yang aktif dan bermakna bagi peserta didik.

Tujuan utama dikembangkannya kurikulum 2013 diharapkan mampu menghasilkan anak-anak yang produktif, kreatif, inovatif, dan efektif melalui penguatan sikap, pengetahuan, dan keterampilan yang terintegrasi. Pendidikan anak usia sekolah dasar yaitu anak yang berusia antara 7 sampai dengan 12 tahun. Sebagai pendidikan di tingkat dasar yang dikembangkan akan memberikan berbagai keterampilan dasar yang akan menjadi pondasi awal pengetahuan siswa. Siswa dapat memperoleh pengalaman langsung sehingga dapat menambah kekuatan untuk menerima, menyimpan, dan menerapkan konsep yang telah dipelajarinya.

Sesuai dengan karakteristik pembelajaran pada anak SD, pemerintah berupaya merancang kurikulum 2013 dengan tujuan untuk mempersiapkan insan Indonesia supaya memiliki kemampuan hidup menjadi pribadi dan warga negara yang beriman, produktif kreatif, inovatif dan afektif serta mampu berkontribusi pada kehidupan bermasyarakat, berbangsa dan peradaban dunia. Sejalan dengan teori (Dantes, 2014: 25) Kurikulum 2013 menuntut adanya inovasi dalam belajar bagaimana menciptakan peserta didik mampu menggali pengetahuannya secara mandiri, pembelajaran yang berpusat pada siswa dan guru sebagai fasilitator sebagai pengarah bukan hanya siswa yang menjadi pusat pembelajaran tetapi guru juga menjadi pusat pembelajaran dimana guru sekarang bertugas sebagai fasilitor guru dituntut untuk lebih kreatif dan inovatif dalam melaksanakan pembelajaran yang sesuai dengan harapan kurikulm 2013 saat ini.

Kesuksesan pengimplementasian kurikulum 2013 untuk menciptakan generasi yang berkualitas ditentukan oleh beberapa faktor, salah satunya adalah fasilitas dan sumber belajar (Mulyasa 2014:39). Buku teks pelajaran dan buku panduan guru memiliki peran penting dalam pembelajaran. Buku teks pelajaran diharapkan mampu membantu peserta didik untuk memahami pelajaran. Buku panduan guru diharapkan mampu membantu guru untuk merancang pembelajaran yang menarik dan menyenangkan, untuk menambah referensi guru mengimplementasikan pembelajaran tematik terpadu. Sedangkan buku siswa berisi kegiatan pembelajaran yang harus dilalui peserta didik untuk mencapai kompetensi yang diharapkan dalam pembelajaran Kurikulum 2013. Peran buku teks sangat penting dalam pelaksanaan dan penilaian pembelajaran di kelas yang sesuai dengan tuntutan Kurikulum 2013. Buku teks yang diterbitkan oleh pemerintah diharapkan dapat mewujudkan tujuan pembelajaran.

Tematik terpadu diberikan dengan maksud menyatukan konten-konten dalam kurikulum dalam tema-tema menjadi satu kesatuan yang utuh sehingga menciptakan pembelajaran lebih bermakna dan mudah dipahami oleh peserta didik, karena pembelajaran tidak dipisah-pisah. Muatan-muatan pelajaran dikemas dalam bentuk tema-tema yang harus disampaikan kepada peserta didik secara utuh dan terpadu. Tematik berasal dari kata tema yang berarti suatu rumusan yang didalamnya terkandung berbagai unsur dan saling terkait. Terpadu adalah kondisi yang mengandung sejumlah unsur dan kemantapan keterkaitan antar unsurunsur yang dimaksud. Materi 
pembelajaran tematik terpadu adalah materi pembelajaran yang dirumuskan dalam bentuk tema yang unsur-unsurnya saling terkait dan terpadu. Unsur-unsur tersebut berasal dari silabus yang memuat berbagai unsur $\mathrm{KI}$ dan KD satu atau beberapa mata pelajaran, kehidupan sehari-hari, pribadi-sosialkemasyarakatan, kondisi alam sekitar, suasana atau kejadian aktual, dalam kesinambungan program pembelajaran muatan pelajaran terkait, sesuai dengan kebutuhan perkembangan peserta didik. Di dalam materi pembelajaran tematikterpadu terintregasikan unsur-unsur pembentukan sikap, pengetahuan, dan keterampilan. Materi pembelajaran tematik terpadu disusun untuk setiap pertemuan pembelajaran.

Pembelajaran terpadu sebagai suatu konsep dapat dikatakan sebagai pendekatan pembelajaran yang melibatkan beberapa muatan pelajaran untuk memberikan pengalaman yang bermakna kepada siswa. Dikatakan bermakna, karena dalam pembelajaran terpadu, siswa akan memahami konsepkonsep yang mereka pelajari melalui pengalaman langsung dan menghubungkan dengan konsep lain yang sudah mereka pahami. Juga disebutkan bahwa pembelajaran terpadu merupakan suatu sistem pembelajaran yang memungkinkan siswa, baik secara individual maupun kelompok, aktif mencari, menggali dan menemukan konsep serta prinsip keilmuan secara holistik, bermakna dan autentik. Hal yang sama juga ditemukan dalam penelitian yang dilakukan Hakim (2014), bahwa pembelajaran tematik integratif pembelajarannya memberikan makna yang utuh kepada peserta didik seperti tercermin pada berbagai tema yang tersedia. Dengan pembelajaran tematik integratif, tema yang dipilih berkenaan dengan alam dan kehidupan manusia. Dengan ini tema-tema yang dipelajari siswa berkaitan dengan kehidupan seharihari siswa. Pembelajaran tematik sangat penting diterapkan di sekolah dasar memiliki banyak nilai dan manfaat, diantaranya: 1) dengan menggabungkan beberapa kompetensi dasar dan indikator serta isi muatan pelajaran akan terjadi penghematan, karena tumpang tindih materi dapat dikurangi bahkan dihilangkan, 2) siswa dapat melihat hubungan-hubungan yang bermakna sebab isi/materi pembelajaran lebih berperan sebagai sarana atau alat ukar tujuan akhir, 3) pembelajaran tidak terpecah-pecah karena siswa dilengkapi dengan pengalaman belajar yang lebih terpadu sehingga akan mendapat pengertian mengenai proses dan materi yang lebih terpadu, 4) memberikan penerapan-penerapan dari dunia nyata sehingga dapat mempertinggi kesempatan transfer belajar. 5) dengan adanya pemanduan antarmuatan pelajaran penguasaan materi pembelajaran akan semakin baik dan meningkat. Hasil penelitian yang dilakukan oleh I. W. Jiwa, N. Dantes, A.A.I.N. Marhaeni (dalam Widistuti, dkk 2019) menyatakan keefektifan model pembelajaran tematik integratif berdasarkan buku guru dan buku siswa atau dengan menggunakan konvensional. Hasil penelitian menunjukkan prestasi belajar siswa lebih unggul dibandingkan dengan pembelajaran konvensional. Sebagaimana diungkapkan Dewey (dalam Sundayana, 2014) bahwa dalam kehidupan nyata kita dihadapkan pada sebagian besar permasalahan dan pengalaman yang bersifat interdisipliner (keterkaitan di antara bidang) ini menuntut kemampuan berkaitan berbagai keterampilan dan berbagai bidang. Dalam kaitan ini kurikulum yang terintegrasi dipandang dapat memberikan kemampuan tersebut.

Namun kenyataan dilapangan
banyak sekali pertanyaan apakah kurikulum 2013 menggunakan tematik integratif, dalam kurikulum 2013 pengelolaan kegiatan pembelajaran di sekolah dasar kelas I sampai VI dilakukan dengan menggunakan pembelajaran tematik terpadu. Dengan demikian, kegiatan menganalisis kompetensi dasar, hasil belajar dan indikator tidak perlu dilakukan secara tersendiri karena dapat dilaksanakan berbarengan dengan penentuan jaringan tema. Hal tersebut di dukung oleh penelitian yang dilakukan oleh (Rhosalia, 2017) Pelaksanaan Kurikulum 2013 versi 2016 yang sedang diterapkan di sekolah dasar saat ini juga 
masih mengunggulkan model pembelajaran tematik terpadu. Dinamakan tematik terpadu karena merupakan perpaduan berbagai kompetensi dari berbagai mata pelajaran ke dalam berbagai tema. Adapun kompetensi yang dipadukan dalam pembelajaran adalah kompetensi spiritual, sikap, keterampilan, dan pengetahuan yang saling berkaitan dalam satu tema. Pertimbangan diterapkan model pembelajaran tematik terpadu ini di sekolah dasar kelas I sampai VI supaya pembelajaran yang digunakan memberikan makna yang utuh kepada peserta didik seperti tercermin dalam tema yang disampaikan.

Selain hal tersebut ada praktik di lapangan banyak guru tidak siap menerapkan kurikulum 2013 yang tematik integratif, berdasarkan hasil wawancara yang dilakukan dilapangan guru mengalami kesulitan dalam menghubungkan muatan pelajaran, selain itu banyaknya kegiatan yang terdapat pada buku siswa yang harus diselesaikan dalam 1 kali pertemuan yang membuat pembelajaran di laksanakan secara tergesa-gesa. Hal tersebut dipicu oleh masih adanya peserta didik yang belum bisa membaca, membedakan huruf, dan angka untuk Kelas I, satu RPP digunakan untuk satu kali pertemuan atau untuk satu pembelajaran, pembelajaran tidak selalu tuntas dalam satu pembelajaran padahal satu pembelajaran harus selesai dalam satu hari, guru merasa kesulitan dalam membagi waktu antara pelaksanaan pembelajaran dan administrasi, serta guru kesulitan dalam melakukan penilaian karena penilaian yang cukup banyak. Hal tersebut juga ditemukan oleh Sari,dkk (2018) Hambatan yang dihadapi oleh pihak sekolah terutama guru dalam implementasi pembelajaran tematik terpadu meliputi penyusunan RPP yang membutuhkan waktu lama, gaya guru mengajar yang kurang bervariasi dan hanya berpedoman pada buku guru sehingga siswa kurang berantusias, adanya siswa yang kurang berani untuk bertanya saat proses pembelajaran, sarana prasarana yang harus dilakukan secara bergantian, penilaian yang rumit karena banyaknya penilaian yang harus dilakukan guru setiap harinya. Selanjutnya
(Permatasari, 2019) menemukan di lapangan pelaksanaan pembelajaran tematik integratif dengan pendekatan saintifik masih mengalami hambatan yaitu guru kurang mengetahui bagaimana pelaksanaan pembelajaran tematik integratif dengan pendekatan saintifik di SD dan penggunaan media serta metode pembelajaran yang kurang mendukung atau kurang variatif sehingga siswa tidak termotivasi untuk belajar.

Berdasarkan pemaparan permasalahan di atas peneliti ingin mengungkap sejauhmana kurikulum 2013 menganut tematik integratif lebih spesifik akan meneliti keintegrasian muatan pelajaran pada materi pelajaran, keintegrasian muatan pelajaran pada rancangan kegiatan pelajaran, keintegrasian muatan pelajaran pada rancangan penilaian, keintegrasian muatan pelajaran pada media dan sumber belajar di buku guru dan buku siswa sekolah dasar kelas I SD tema Benda, Hewan dan Tanaman di Sekitarku. Maka peneliti mengungkap judul penelitian "Analisis Keintegrasi Muatan Pelajaran Sekolah Dasar Kelas I Tema Benda, Hewan dan Tanaman di Sekitarku Dalam Implementasi Kurikulum 2013" . Analisis dilakukan terfokus pada buku guru dan buku siswa.

\section{METODE}

Pengembangan Kurikulum menjadi salah satu upaya pemerintah untuk menciptakan pendidikan yang berkualitas. Mengingat pentingnya kurikulum dalam pendidikan dan kehidupan manusia, maka penyusunan kurikulum dilakukan untuk mewujudkan proses berkembangnya kualitas potensi peserta didik. Kurikulum yang pernah digunakan yaitu mulai dari Kurikulum Berbasis Kompetensi (KBK), Kurikulum Tingkat Satuan Pendidikan (KTSP) dan yang terbaru Kurikulum 2013. Pembaharuan kurikulum diharapkan mampu mengubah pola pembelajaran yang awalnya berpusat pada guru (teacher centered) menjadi berpusat pada siswa (student centered). Penerapan kurikulum 2013 menjadi tantangan sekaligus peluang bagi tenaga pendidik yang menjadi garda terdepan demi mewujudkan cita-cita pendidikan. Namun 
tentu saja semua itu tergantung oleh dukungan masyarakat dan khususnya pelaku pendidikan itu sendiri seperti guru dan kepala sekolah dan juga peserta didik serta orang tua peserta didik. Banyak hal yang menjadi kendala yang menjadi bagian dari penerapan Kurikulum 2013 salah satunya adalah kesiapan guru mengemas pembelajaran sesuai dengan prosedur kurikulum baik dalam pemaparan materi sesuai tema, dengan tema, rancangan pembelajaran, penilaian serta penggunaan media pembelajaran sebagai pendukung proses pembelajaran yang aktif dan bermakna bagi peserta didik.

Tujuan utama dikembangkannya kurikulum 2013 diharapkan mampu menghasilkan anak-anak yang produktif, kreatif, inovatif, dan efektif melalui penguatan sikap, pengetahuan, dan keterampilan yang terintegrasi. Pendidikan anak usia sekolah dasar yaitu anak yang berusia antara 7 sampai dengan 12 tahun. Sebagai pendidikan di tingkat dasar yang dikembangkan akan memberikan berbagai keterampilan dasar yang akan menjadi pondasi awal pengetahuan siswa. Siswa dapat memperoleh pengalaman langsung sehingga dapat menambah kekuatan untuk menerima, menyimpan, dan menerapkan konsep yang telah dipelajarinya.

Sesuai dengan karakteristik pembelajaran pada anak SD, pemerintah berupaya merancang kurikulum 2013 dengan tujuan untuk mempersiapkan insan Indonesia supaya memiliki kemampuan hidup menjadi pribadi dan warga negara yang beriman, produktif kreatif, inovatif dan afektif serta mampu berkontribusi pada kehidupan bermasyarakat, berbangsa dan peradaban dunia. Sejalan dengan teori (Dantes, 2014: 25) Kurikulum 2013 menuntut adanya inovasi dalam belajar bagaimana menciptakan peserta didik mampu menggali pengetahuannya secara mandiri, pembelajaran yang berpusat pada siswa dan guru sebagai fasilitator sebagai pengarah bukan hanya siswa yang menjadi pusat pembelajaran tetapi guru juga menjadi pusat pembelajaran dimana guru sekarang bertugas sebagai fasilitor guru dituntut untuk lebih kreatif dan inovatif dalam melaksanakan pembelajaran yang sesuai dengan harapan kurikulm 2013 saat ini.

Kesuksesan pengimplementasian kurikulum 2013 untuk menciptakan generasi yang berkualitas ditentukan oleh beberapa faktor, salah satunya adalah fasilitas dan sumber belajar (Mulyasa 2014:39). Buku teks pelajaran dan buku panduan guru memiliki peran penting dalam pembelajaran. Buku teks pelajaran diharapkan mampu membantu peserta didik untuk memahami pelajaran. Buku panduan guru diharapkan mampu membantu guru untuk merancang pembelajaran yang menarik dan menyenangkan, untuk menambah referensi guru mengimplementasikan pembelajaran tematik terpadu. Sedangkan buku siswa berisi kegiatan pembelajaran yang harus dilalui peserta didik untuk mencapai kompetensi yang diharapkan dalam pembelajaran Kurikulum 2013. Peran buku teks sangat penting dalam pelaksanaan dan penilaian pembelajaran di kelas yang sesuai dengan tuntutan Kurikulum 2013. Buku teks yang diterbitkan oleh pemerintah diharapkan dapat mewujudkan tujuan pembelajaran.

Tematik terpadu diberikan dengan maksud menyatukan konten-konten dalam kurikulum dalam tema-tema menjadi satu kesatuan yang utuh sehingga menciptakan pembelajaran lebih bermakna dan mudah dipahami oleh peserta didik, karena pembelajaran tidak dipisah-pisah. Muatan-muatan pelajaran dikemas dalam bentuk tema-tema yang harus disampaikan kepada peserta didik secara utuh dan terpadu. Tematik berasal dari kata tema yang berarti suatu rumusan yang didalamnya terkandung berbagai unsur dan saling terkait. Terpadu adalah kondisi yang mengandung sejumlah unsur dan kemantapan keterkaitan antar unsurunsur yang dimaksud. Materi pembelajaran tematik terpadu adalah materi pembelajaran yang dirumuskan dalam bentuk tema yang unsur-unsurnya saling terkait dan terpadu. Unsur-unsur tersebut berasal dari silabus yang memuat berbagai unsur $\mathrm{KI}$ dan $\mathrm{KD}$ satu atau beberapa mata pelajaran, kehidupan sehari-hari, pribadi-sosialkemasyarakatan, kondisi alam sekitar, 
suasana atau kejadian aktual, dalam kesinambungan program pembelajaran muatan pelajaran terkait, sesuai dengan kebutuhan perkembangan peserta didik. Di dalam materi pembelajaran tematikterpadu terintregasikan unsur-unsur pembentukan sikap, pengetahuan, dan keterampilan. Materi pembelajaran tematik terpadu disusun untuk setiap pertemuan pembelajaran.

Pembelajaran terpadu sebagai suatu konsep dapat dikatakan sebagai pendekatan pembelajaran yang melibatkan beberapa muatan pelajaran untuk memberikan pengalaman yang bermakna kepada siswa. Dikatakan bermakna, karena dalam pembelajaran terpadu, siswa akan memahami konsepkonsep yang mereka pelajari melalui pengalaman langsung dan menghubungkan dengan konsep lain yang sudah mereka pahami. Juga disebutkan bahwa pembelajaran terpadu merupakan suatu sistem pembelajaran yang memungkinkan siswa, baik secara individual maupun kelompok, aktif mencari, menggali dan menemukan konsep serta prinsip keilmuan secara holistik, bermakna dan autentik. Hal yang sama juga ditemukan dalam penelitian yang dilakukan Hakim (2014), bahwa pembelajaran tematik integratif pembelajarannya memberikan makna yang utuh kepada peserta didik seperti tercermin pada berbagai tema yang tersedia. Dengan pembelajaran tematik integratif, tema yang dipilih berkenaan dengan alam dan kehidupan manusia. Dengan ini tema-tema yang dipelajari siswa berkaitan dengan kehidupan seharihari siswa. Pembelajaran tematik sangat penting diterapkan di sekolah dasar memiliki banyak nilai dan manfaat, diantaranya: 1) dengan menggabungkan beberapa kompetensi dasar dan indikator serta isi muatan pelajaran akan terjadi penghematan, karena tumpang tindih materi dapat dikurangi bahkan dihilangkan, 2) siswa dapat melihat hubungan-hubungan yang bermakna sebab isi/materi pembelajaran lebih berperan sebagai sarana atau alat ukar tujuan akhir, 3) pembelajaran tidak terpecah-pecah karena siswa dilengkapi dengan pengalaman belajar yang lebih terpadu sehingga akan mendapat pengertian mengenai proses dan materi yang lebih terpadu, 4) memberikan penerapan-penerapan dari dunia nyata sehingga dapat mempertinggi kesempatan transfer belajar. 5) dengan adanya pemanduan antarmuatan pelajaran penguasaan materi pembelajaran akan semakin baik dan meningkat. Hasil penelitian yang dilakukan oleh I. W. Jiwa, N. Dantes, A.A.I.N. Marhaeni (dalam Widistuti, dkk 2019) menyatakan keefektifan model pembelajaran tematik integratif berdasarkan buku guru dan buku siswa atau dengan menggunakan konvensional. Hasil penelitian menunjukkan prestasi belajar siswa lebih unggul dibandingkan dengan pembelajaran konvensional. Sebagaimana diungkapkan Dewey (dalam Sundayana, 2014) bahwa dalam kehidupan nyata kita dihadapkan pada sebagian besar permasalahan dan pengalaman yang bersifat interdisipliner (keterkaitan di antara bidang) ini menuntut kemampuan berkaitan berbagai keterampilan dan berbagai bidang. Dalam kaitan ini kurikulum yang terintegrasi dipandang dapat memberikan kemampuan tersebut.

Namun kenyataan dilapangan banyak sekali pertanyaan apakah kurikulum 2013 menggunakan tematik integratif, dalam kurikulum 2013 pengelolaan kegiatan pembelajaran di sekolah dasar kelas I sampai VI dilakukan dengan menggunakan pembelajaran tematik terpadu. Dengan demikian, kegiatan menganalisis kompetensi dasar, hasil belajar dan indikator tidak perlu dilakukan secara tersendiri karena dapat dilaksanakan berbarengan dengan penentuan jaringan tema. Hal tersebut di dukung oleh penelitian yang dilakukan oleh (Rhosalia, 2017) Pelaksanaan Kurikulum 2013 versi 2016 yang sedang diterapkan di sekolah dasar saat ini juga masih mengunggulkan model pembelajaran tematik terpadu. Dinamakan tematik terpadu karena merupakan perpaduan berbagai kompetensi dari berbagai mata pelajaran ke dalam berbagai tema. Adapun kompetensi yang dipadukan dalam pembelajaran adalah kompetensi spiritual, sikap, keterampilan, dan pengetahuan yang saling berkaitan 
dalam satu tema. Pertimbangan diterapkan model pembelajaran tematik terpadu ini di sekolah dasar kelas I sampai $\mathrm{VI}$ supaya pembelajaran yang digunakan memberikan makna yang utuh kepada peserta didik seperti tercermin dalam tema yang disampaikan.

Selain hal tersebut ada praktik di lapangan banyak guru tidak siap menerapkan kurikulum 2013 yang tematik integratif, berdasarkan hasil wawancara yang dilakukan dilapangan guru mengalami kesulitan dalam menghubungkan muatan pelajaran, selain itu banyaknya kegiatan yang terdapat pada buku siswa yang harus diselesaikan dalam 1 kali pertemuan yang membuat pembelajaran di laksanakan secara tergesa-gesa. Hal tersebut dipicu oleh masih adanya peserta didik yang belum bisa membaca, membedakan huruf, dan angka untuk Kelas I, satu RPP digunakan untuk satu kali pertemuan atau untuk satu pembelajaran, pembelajaran tidak selalu tuntas dalam satu pembelajaran padahal satu pembelajaran harus selesai dalam satu hari, guru merasa kesulitan dalam membagi waktu antara pelaksanaan pembelajaran dan administrasi, serta guru kesulitan dalam melakukan penilaian karena penilaian yang cukup banyak. Hal tersebut juga ditemukan oleh Sari,dkk (2018) Hambatan yang dihadapi oleh pihak sekolah terutama guru dalam implementasi pembelajaran tematik terpadu meliputi penyusunan RPP yang membutuhkan waktu lama, gaya guru mengajar yang kurang bervariasi dan hanya berpedoman pada buku guru sehingga siswa kurang berantusias, adanya siswa yang kurang berani untuk bertanya saat proses pembelajaran, sarana prasarana yang harus dilakukan secara bergantian, penilaian yang rumit karena banyaknya penilaian yang harus dilakukan guru setiap harinya. Selanjutnya (Permatasari, 2019) menemukan di lapangan pelaksanaan pembelajaran tematik integratif dengan pendekatan saintifik masih mengalami hambatan yaitu guru kurang mengetahui bagaimana pelaksanaan pembelajaran tematik integratif dengan pendekatan saintifik di SD dan penggunaan media serta metode pembelajaran yang kurang mendukung atau kurang variatif sehingga siswa tidak termotivasi untuk belajar.

Berdasarkan

pemaparan permasalahan di atas peneliti ingin mengungkap sejauhmana kurikulum 2013 menganut tematik integratif lebih spesifik akan meneliti keintegrasian muatan pelajaran pada materi pelajaran, keintegrasian muatan pelajaran pada rancangan kegiatan pelajaran, keintegrasian muatan pelajaran pada rancangan penilaian, keintegrasian muatan pelajaran pada media dan sumber belajar di buku guru dan buku siswa sekolah dasar kelas I SD tema Benda, Hewan dan Tanaman di Sekitarku. Maka peneliti mengungkap judul penelitian "Analisis Keintegrasi Muatan Pelajaran Sekolah Dasar Kelas I Tema Benda, Hewan dan Tanaman di Sekitarku Dalam Implementasi Kurikulum 2013" . Analisis dilakukan terfokus pada buku guru dan buku siswa.

Tabel 1. Konvensi Penilaian Acuan Patokan (PAP) Skala Lima Tentang Keintegrasian Muatan Pelajaran

\begin{tabular}{cc}
\hline Presentase Pencapaian (\%) & Validitas \\
\hline $90-100$ & Sangat Baik \\
$80-89$ & Baik \\
$65-79$ & Sedang \\
$40-64$ & Rendah \\
$00-39$ & Sangat Rendah \\
\hline
\end{tabular}

(Sumber: Modifikasi Agung, 2016: 146)

1. Penyajian Data

Setelah penggolongan data, maka langkah selanjutnya adalah menyajikan data. Pada penelitian kualitatif penyajian data bisa dilakukan dalam bentuk uraian singkat, bagan, hubungan antar kategori, 
flowchart, dan sejenisnya. Data yang disajikan dalam penelitian ini berbentuk rangkuman secara deskriptif dan sistematis dari hasil yang diperoleh, sehingga tema sentral dapat diketahui dengan mudah, dan setiap rangkuman diberikan penjelasan dengan memperhatikan kesesuaian dengan fokus penelitian. Akan tetapi, dalam penyajian data dalam penelitian ini juga menggunakan tabel untuk memudahkan dalam pengkategorian. Diharapkan dari data yang diperoleh akan memudahkan dan menjelaskan apa yang terjadi.

\section{Menarik Kesimpulan/ Verifikasi}

Langkah yang terakhir adalah verifikasi data untuk menarik kesimpulan. Kesimpulan dalam penelitian kualitatif dapat menjawab rumusan masalah yang dirumuskan sejak awal, tetapi mungkin juga tidak karena masalah dan rumusan masalah dalam penelitian kualitatif masih bersifat sementara dan berkembang saat penelitian berada di lapangan.

\section{HASIL DAN PEMBAHASAN}

Tabel 2. Hasil Analisis Keintegrasian Empat Komponen Pembelajaran

\begin{tabular}{|c|c|c|c|c|}
\hline \multirow[b]{2}{*}{$\begin{array}{c}\text { Komponen } \\
\text { Pembelajaran }\end{array}$} & \multicolumn{3}{|c|}{ Klasifikasi Keintegrasian } & \multirow[t]{2}{*}{ Presentase (\%) } \\
\hline & $\begin{array}{c}\text { Tidak } \\
\text { Terdapat } \\
\text { Keintegrasian }\end{array}$ & $\begin{array}{c}\text { Integrasi } \\
\text { Intradisipliner }\end{array}$ & $\begin{array}{c}\text { Integrasi } \\
\text { Multidisipliner }\end{array}$ & \\
\hline $\begin{array}{l}\text { Materi } \\
\text { Pembelajaran (MP) }\end{array}$ & 5 & 38 & 13 & 91,07 \\
\hline $\begin{array}{l}\text { Rancangan } \\
\text { Langkah-Langkah } \\
\text { Kegiatan } \\
\text { Pembelajaran } \\
\text { (RLLKP) }\end{array}$ & 6 & 54 & 18 & 92,31 \\
\hline $\begin{array}{l}\text { Rancangan } \\
\text { Penilaian (RP) }\end{array}$ & 11 & 63 & 0 & 85,13 \\
\hline $\begin{array}{l}\text { Rancangan Media } \\
\text { dan Sumber Belajar } \\
\text { (RMSB) }\end{array}$ & 5 & 19 & 6 & 83,33 \\
\hline TOTAL & 27 & 174 & 39 & 89,00 \\
\hline
\end{tabular}

Berdasarkan Tabel 2. hasil analisis keintegrasian muatan pelajaran pada 4 komponen pembalajaran di atas dapat disimpulkan bahwa terdapat keintegrasian yang ditemukan pada materi pembelajaran (RP), rancangan langkah-langkah kegiatan pembelajaran (RLLKP), rancangan penilaian (RP), rancangan media dan sumber belajar (RMSB). Klasifikasi keintegrasian pada 4 komponen pembelajaran yaitu pertama, komponen materi pembelajaran (MP) ditemukan 5 yang tidak terdapat keintegrasian, 38 keintegrasian secara intradisipliner dan 13 keintegrasian secara multidisipliner. Sehingga dapat disimpulkan kecenderungan keintegrasian pada komponen materi pembelajaran (MP) yaitu integrasi intradisipliner dengan presentase $91,07 \%$ tingkat keintegrasian sangat baik.
Kedua, komponen rancangan langkahlangkah kegiatan pembelajaran (RLLKP) ditemukan 6 yang tidak terdapat keintegrasian, 54 keintegrasian secara intradisipliner dan 18 keintegrasian secara multidisipliner. Sehingga dapat disimpulkan kecenderungan keintegrasian pada komponen rancangan langkahlangkah kegiatan pembelajaran (RLLKP) yaitu integrasi intradisipliner dengan presentase $92,30 \%$ tingkat keintegrasian sangat baik. Ketiga, komponen rancangan penilaian (RP) ditemukan 11 yang tidak terdapat keintegrasian, 63 keintegrasian secara intradisipliner, sedangkan untuk keintegrasian secara multidisipliner 0 . Sehingga dapat disimpulkan kecenderungan keintegrasian pada komponen rancangan penilaian (RP) yaitu integrasi intradisipliner dengan presentase 
$85,13 \%$ tingkat keintegrasian baik. Keempat, komponen rancangan media dan sumber belajar (RMSB) ditemukan 5 yang tidak terdapat keintegrasian, 19 keintegrasian secara intradisipliner dan ditemukan 6 keintegrasian secara multidisipliner. Sehingga dapat disimpulkan kecenderungan keintegrasian pada komponen rancangan media dan sumber belajar (RMSB) yaitu integrasi intradisipliner dengan presentase 83,33\% tingkat keintegrasian baik.

Berdasarkan pemaparan hasil analisis keintegrasian muatan pelajaran pada 4 komponen pembalajaran ditemukan 27 yang tidak terdapat keintegrasian, 174 keintegrasian secara intradisipliner dan ditemukan 39 keintegrasian secara multidisipliner. Sehingga dapat disimpulkan kecenderungan keintegrasian muatan pelajaran pada 4 komponen pembelajaran di buku guru dan buku siswa sekolah dasar kelas I tema Benda, Hewan dan Tanaman di Sekitarku secara keseluruhan yaitu integrasi intradisipliner (174 keintegrasian) dengan presentase $89,00 \%$ tingkat keintegrasian baik.

Berdasarkan hasil analisis keempat komponen pembelajaran yaitu, (1) materi pembelajaran (2) rancangan langkahlangkah kegiatan pembelajaran, (3) rancangan penilaian, (4) rancangan media dan sumber belajaran pada buku guru dan buku siswa sekolah dasar kelas I tema Benda, Hewan dan Tanaman di Sekitarku menunjukkan bahwa terdapat keintegrasian muatan pelajaran pada keempat komponen pembelajaran dengan kategori baik, keintegrasian lebih cenderung integrasi intradisipliner. Integrasi intradisipliner terjadi akibat terintegrasinya sikap, pengetahuan dan keterampilan dalam satu muatan pmbelajaran. Temuan ini relevan Murfiah (2106) integrasi intradisipliner dilakukan dengan cara mengintegrasikan dimensi sikap, pengetahuan, dan keterampilan menjadi satu kesatuan utuh di setiap mata pelajaran. Hal tersebut sejalan dengan pendapat Selain itu penemuan dalam penelitian ini yaitu muatan pelajaran yang ada pada kelas awal yaitu muatan pelajaran Bahasa Indonesia, PPKn, SBdP, PJOK dan Matematika. Pengintegrasian multidisipliner selalu melibatkan muatan pelajaran Bahasa Indonesia dengan muatan pelajaran lainnya. Sehingga muatan pelajaran Bahasa Indonesia dapat dikatakan sebagai pembuka keintegrasian. Muatan pelajaran bahasa Indonesia pada hakikatnya adalah pengajaran keterampilan berbahasa, bukan pengajaran tentang bahasa. Menurut Cahyani (2012:27) bahasa Indonesia secara garis besar terdiri atas enam aspek mendengarkan, berbicara, membaca, menulis, kebahasaan, dan apresiasi bahasa dan sastra Indonesia. Melalui membaca, menulis, mendengarkan, dan berbicara siswa mampu mengembangkan kemampuan berpikir logis, kritis, kreatif, inovatif dan inventif terus-menerus yang akan diteruskan juga melalui muatan pelajaran yang lain. Hal sama juga disampaikan oleh Gunawan (2012:366) bahwa satu dari dua bidang studi yang sangat penting dan sangat mempengaruhi konsep diri anak adalah kemampuan membaca dan menulis.

Sedangkan materi IPA di SD kelas awal terintegrasi dalam mata pelajaran Bahasa Indonesia dan pendidikan jasmani olahraga dan kesehatan. Integrasi IPA di tingkat kelas awal ini menggunakan pendekatan integrasi intradisipliner dan interdisipliner. Pembelajaran dilakukan secara terpadu dalam tema dengan mata pelajaran lain. Dalam pendekatan interdisipliner, rumusan Kompetensi Dasar IPA melebur ke dalam mata pelajaran lainnya sehingga secara eksplisit tidak terlihat rumusan kompetensidasarnya. Dengan kata lain, mata pelajaran IPA diintegrasikan secara multidisipliner di kelas tinggi. Selanjutnya sama halnya dengan materi muatan pelajaran IPS sebagai bagian integral dari muatan pelajaran lain, yaitu bahasa Indonesia dan PPKn yang diajarkan secara tematik terpadu dengan pendekatan intradisipliner dan interdisipliner. Temuan ini relevan dengan Prastowo (2019) menyatakan bahwa muatan pelajaran Bahasa Indonesia terintegrasi dalam seluruh pembelajaran. Berikut pembahasan dari masing-masing komponen.

$$
\text { Pertama, materi pembelajaran }
$$
memiliki kecendrungan keintegrasian 
intradisipliner dengan nilai presentase 91,07\% berkategori sangat baik. Artinya materi pembelajaran pada tema Benda, Hewan, Tanaman di Sekitarku kelas I SD memiliki keintegrasian lebih cendereng pada integrasi intradisipliner yaitu pengintegrasian sikap, pengetahuan dan keterampilan pada satu muatan pelajaran memfasilitasi lebih dari satu tujuan pembelajaran pada muatan pelajaran yang sama. Materi yang dituangkan pada buku siswa selalu mengaitkan dengan kehidupan nyata, kontekstual, terpusat pada siswa aktif dalam mengembangkan berbagai kompetensi siswa melalui penyajian tema yang jelas dan menghubungkan antara konsep dan ide yang dipahami dalam kehidupan seharihari sehingga materi pembelajaran tertanam dalam ingatan siswa sehingga pembelajaran lebih bermakna. Hasil penelitian Terbukti dengan penelitian yang dilakukan olehl. W. Jiwa, N. Dantes, A.A.I.N. Marhaeni dalam Widistuti, dkk (2019) menyatakan keefektifan model pembelajaran tematik integratif berdasarkan buku guru dan buku siswa atau dengan menggunakan konvensional. Hasil penelitian menunjukkan prestasi belajar siswa lebih unggul dibandingkan dengan pembelajaran konvensional. Lebih lanjut Widiastusi, dkk (2019) menerangkan bahwa materi pembelajaran pada buku siswa kurikulum 2013 dikemas secara utuh serta melibatkan secara aktif meliputi aspek pengetahuan sikap, dan keterampilan dalam menggali pengetahuan dari berbagai sumber berkaitan dengan pengalaman siswa secara langsung. Hasil penelitian yang juga dilakukan oleh Millah \& Syah (2017) pembelajaran tematik integratif sesuai dengan karakteristik siswa dengan materi peserta didik dapat memperoleh pengelaman langsung dan terlatih untuk dapat menemukan sendiri berbagai pengetahuan yang dipelajarinya, memahami konsep yang mereka pelajari dan menguhungkannya dengan konsep lain. Pengalaman belajar yang menunjukkan kaitan unsur-unsur konseptual menjadikan proses pembelajaran lebih efekif sehingga peserta didik akan memperoleh keutuhan dan kebulatan pengetahuan. Selanjutnya dalam penelitian ini juga ditemukan pada materi pembelajaran secara tidak langsung terdapat tulisan-tulisan yang mengandung nilai-nilai kompetensi sikap sosial. Berikut contoh materi pembelajaran pada tema Benda, Hewan, dan Tanaman di Sekitarku.

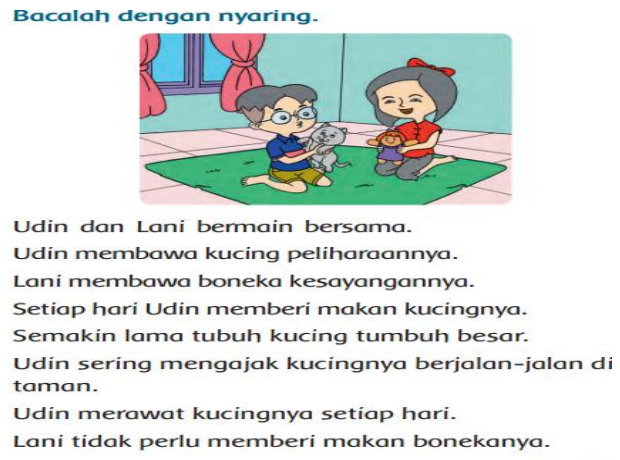

Merujuk pada gambar di atas materi pada buku siswa, secara tidak langsung terdapat teks bacaan yang didalamnya mengandung nilai-nilai kompetensi sikap sebagai dampak pengriring (nurturant effect) yaitu Udin dan Lani sama-sama memiliki benda yang mereka sayangi, pada teks bacaan terselip sikap peduli Udin merawat kucingnya dengan baik. Artinya pada materi pembelajaran tersebut menjadi pengalaman belajar anak untuk memiliki rasa peduli, tanggung jawab dengan apa yang ia miliki. Penemuan tersebut sejalan dengan Sukayati (dalam Pratowo 2019), bahwa dalam pembelajaran tematik integratif menumbuh kembangkan sikap positif, kebiasaan baik dan nilai-nilai luhur yang diperlukan dalam kehidupan serta menumbuhkembangkan keterampilan sosial. Dengan demikian pada komponen materi pembelajaran pada buku siswa cocok dan baik di implemantasikan pada jenjang sekolah dasar yaitu pada kelas awal.

Kedua, keintegrasian rancangan langkah-langkah kegiatan pembelajaran memiliki kecendrungan keintegrasian intradisipliner dengan nilai presentase sebesar 92,31\% dengan kategori sangat baik. Analisis tersebut menyakinkan bahwa kegiatan pembelajaran pada buku siswa terjadi integrasi kompetensi (sikap, pengetahuan, dan keterampilan) menjadi satu kesatuan yang utuh dari satu muatan pelajaran melalui aktivitas yang bervariasi yang memuat kegiatan mengamati, 
menanya, mengumpulkan informasi, mengasosiasi, dan mengomunikasikan. Setiap pembelajaran pada masing-masing buku memiliki kegiatan yang dilakukan oleh siswa dibuat ikon-ikon yang melambangkannya misalnya, kegiatan "Ayo Mengamati, Ayo Berlatih dan Ayo Bercerita. Berikut contoh rancangan langkah-langkah kegiatan siswa pada buku siswa". Rancangan Langkahlangkah kegiatan pembelajaran tema 7 sub tema 2 pembelajaran 1 terdapat kegiatan (1) Ayo mengamati siswa membaca teks tentang Hewan Peliharaan Beni pada kegiatan membaca guru memberikan penekanan kepada siswa untuk membaca dengan tertib tidak menggangu teman secara langsung kegiatan tersebut mengembangkan kompetensi sikap.(2) Kegiatan Ayo Berlatih, melalui kegiatan mengamati, kemudian siswa berlatih menuliskan aturan merawat hewan sesuai dengan pengalamannya, lalu menuliskan aturan merawat hewan peliharaan, melalui kegitan ayo berlatih dikembangkannya kompetensi pengetahuan, dan yang (3) yaitu kegiatan ayo bercerita, siswa berlatih menceritakan cara merawat hewan, kegiatan tersebut mengembangkan kompetensi keterampilan. Lebih lanjut, Rusman (2016:152) menyatakan pembelajaran tematik integratif memiliki keunggulan diantaranya, pertama pengalaman dan kegiatan belajar sangat relevan dengan tingkat perkembangan dan kebutuhan anak usia sekolah dasar, kedua kegiatan-kegiatan yang dipilih dalam rancangan langkah-langkah kegiatan pembelajaran bertolak dari minat dan kebutuhan siswa, selanjutnya ketiga, kegiatan belajar akan lebih bermakna dan berkesan bagi siswa sehingga hasil belajar dapat bertahan lebih lama selain itu membantu mengembangkan keterampilan berpikir siswa, beliau juga membuat pernyataan bahwa penyajian rancangan kegiatan pembelajaran bersifat pragmatis sesuai dengan permasalahan yang sering ditemui dalam lingkungannya dan juga mengembangkan keterampilan sosial siswa seperti kerjasama, toleransi, komunikasi dan tanggap terhadap gagasan orang lain. Sejalan dengan Widiastuti dan Astuti (2019), untuk mengarahkan siswa secara aktif dalam mengikuti kegiatan pembelajaran melalui kegiatan mengamati, bertanya, menalar, mencoba dan berdiskusi serta meningkatkan kemampuan berkomunikasi antar teman dan gurunya secara baik.

Ketiga, keintegrasian rancangan penilaian pembelajaran tematik integratif memiliki kecendrungan keintegrasian intradisipliner dengan nilai presentase sebesar $85,13 \%$ dengan kategori baik. Rancangan penilaian yang termuat pada tema Benda, Hewan dan Tanaman di Sekitarku yaitu peniaian autentik meliputi prosedur yang digunakan, jenis dan bentuk penilaian, serta alat evaluasi yang digunakan. Penilaian tersebut disesuaikan dengan penilaian autentik yaitu dalam bentuk penilaian proyek, penilaian portofolio dan penilaian kinerja dan tes. Dalam penilaian pembelajaran tematik terpadu mencangkup penilaian terhadap proses dan hasil belajar siswa. Penilaian proses belajar adalah upaya pemberian nilai terhadap kegiatan pembelajaran yang dilakukan oleh guru dan siswa, sedangkan penilaian hasil belajar proses pemberian nilai-nilai terhadap hasil-hasil belajar yang dicapai dengan kriteria tertentu. Hasil belajar tersebut pada hakikatnya kompetensi-kompetensi yang mencangkup aspek pengetahuan, keterampilan, sikap dan nilai-nilai yang diwujudkan dalam kebiasaan berpikir dan bertindak. Kompetensi tersebut dapat dikenali melalui sejumlah hasil belajar dan indikatornya yang dapat diukur dan diamati. Penilaian proses dan hasil belajar itu saling berkaitan satu dengan lainnya, hasil belajar merupakan akibat dari suatu proses belajar. Maryati (2019) juga menyatakan hal sama terkait dengan penilaian pada pembelajaran tematik terpadu Authentic assessment measures competencies of attitude, skills, and knowledge, based on process and results. The results of authentic assessment are used by teachers to plan programs. Dengan demikian, penilaian autentik sangat bermakna bagi guru untuk menentukan cara-cara terbaik agar semua peserta didik dapat mecapai hasil akhir, meski dengan satuan waktu yang berbeda. Kontruksi sikap, keterampilan dan pengetahuan dicapai melalui 
penyelesaian tugas dimana peserta didik telah memainkan peran aktif dan kreatif. Keterlibatan peserta didik dalam melaksanakan tugas sangat bermakna bagi perkembangan pribadi mereka. Selanjutnya Rusman (2016:251), menyebutkan penilaian autentik pada pembelajaran tematik mendorong peserta didik mengonstruksi, mengorganisasikan, menganalisis, mensintesis, menafsirkan, menjelaskan dan mengevaluasi informasi untuk kemudian mengubahnya menjadi pengetahuan baru. Sehingga rancangan penilaian yang digunakan pada buku guru dan siswa kelas I tema Benda, Hewan dan Tanaman di Sekitarku baik diimplementasikan sebagai suatu proses pengumpulan, pelaporan dan penggunaan informasi tentang hasil belajar peserta didik sesuai dengan kompetensi yang akan dicapai.

Keempat, keintegrasian rancangan media dan sumber belajar tematik integratif memiliki kecendrungan keintegrasian intradisipliner dengan nilai presentase sebesar $83,33 \%$ dengan kategori baik. Hal ini menunjukkan bahwa terdapat keintegrasian muatan pelajaran pada rancangan media dan sumber belajar. Anak usia sekolah dasar masih berpkir operasional konkret artinya pembelajaran yang dilakukan harus konkret dekat dengan kehidupan siswa sehingga mudah untuk dipahami oleh siswa, untuk itu penggunaan media dan sumber belajar merupakan suatu keniscayaan atau keharusan kalau ingin mendapatkan hasil belajar yang optimal. Tanpa media yang bervariasi maka pelaksanaan kegiatan pembelajaran tematik terpadu tidak akan berjalan dengan efektif. Pada buku siswa tema Benda, Hewan dan Tanaman di Sekitarku ditemukan media gambar tentang manusia, binatang, tempat atau objek lain yang ada kaitanya dengan tema. Temuan ini relevan dengan pendapat Rusman (2016:177) penggunaan media dalam pelaksanaan pembelajaran tematik terpadu dapat divariasikan ke dalam penggunaan media visual, media audio, dan media audio-visual. Dengan menggunakan media pembelajaran dapat memberikan keefektifan dalam proses pembelajaran. Selajutnya media pembelajaran tematik tema 7 dijadikan sebagai bagian integral dengan komponen pembelajaran lainnya, dalam arti tidak berdiri sendiri tetapi saling berhubungan dengan komponen lainnya dalam rangka menciptakan situasi belajar yang bermakna. Lebih lanjut Rusman (2016) menyebutkan beberapa nilai yang dapat dipetik dari penggunaan media dalam pembelajaran tematik terpadu diantaranya dapat mengkonkretkan konsep-konsep yang abstrak, menghadirkan obejk-objek yang terlalu berbahaya atau sukar di dapat ke dalam lingkungan belajar, menampilkan objek yang terlalu besar atau terlalu kecil. Hal tersebut sejalan dengan hasil penelitian Najmi (2020), media pembelajaran merupakan alat atau perangkat untuk menyampaikan pesanpesan materi kepada siswa; media belajar mampu membuat siswa menjadi lebih memahami pembelajaran; media belajar dapat meningkatkan motivasi belajar siswa; dan media belajar terbukti efektif untuk digunakan dalam proses belajar mengajar.

\section{PENUTUP}

Berdasarkan hasil penelitian dan pembahasan di atas, maka peneliti menyimpulkan sebagai berikut: (1) Terdapat keintegrasian muatan pelajaran pada materi pelajaran (MP) sekolah dasar kelas I tema Benda, Hewan, dan Tanaman di Sekitarku yaitu cenderung pada klasifikasi integrasi intradisipliner dengan presentase 91,07\% berada pada kategori sangat baik. (2) Terdapat keintegrasian muatan pelajaran pada rancangan langkah-langkah kegiatan pembelajaran (RLLKP) di buku guru dan buku siswa sekolah dasar kelas I tema Benda, Hewan, dan Tanaman di Sekitarku yaitu cenderung pada klasfikasi integrasi intradisipliner dengan presentase 92,31\% berada pada kategori sangat baik. (3) Terdapat keintegrasian muatan pelajaran pada rancangan penilaian (RP) di buku guru dan buku siswa sekolah dasar kelas kelas I tema Benda, Hewan, dan Tanaman di Sekitarku yaitu cenderung pada klasfikasi integrasi intradisipliner dengan presentase $85,13 \%$ berada pada kategori sangat baik. (4) Terdapat keintegrasian muatan pelajaran pada rancangan media 
dan sumber belajar (RMSB) di buku guru dan buku siswa sekolah dasar kelas I tema Benda, Hewan, dan Tanaman di Sekitarku yaitu cenderung pada klasfikasi integrasi intradisipliner dengan presentase $83,33 \%$ berada pada kategori sangat baik.

Berdasarkan simpulan hasil penelitian analisis keintegrasian muatan pelajaran pada buku guru dan buku siswa sekolah dasar kelas I tema Benda, Hewan, dan Tanaman di Sekitarku, berikut disampaikan saran untuk menindak lanjuti penelitian ini agar lebih berkualitas sehingga dapat digunakan dalam proses pembelajaran, antara lain:

1. Bagi Guru

Guru seharusnya selalu memperbaharui proses pembelajaran yang akan diterapkan di setiap kelas. Dalam konkretnya guru diharapkan betulbetul paham, menggunakan pembelajaran tematik terpadu tidak hanya terfokus pada buku siswa namun mencari reverensi untuk memperkaya materi pembelajaran, sehingga pembelajaran dapat bervariasi dan tidak monoton hanya dengan satu jenis sesuai dengan buku siswa.

2. Bagi Lembaga Sekolah

Seperti saran yang telah disampaikan untuk guru tentunya hal ini dituntut lembaga sekolah memberikan stimulus kepada guru-guru SD ini keberbagai kegiatan diklat, bimtek, workshop dan lain-lain guna memberikan pelatihan yang dapat menambah wawasan guru terkait dengan keintegrasian muatan pelajaran serta menerapkan pembelajaran tematik terpadu dengan semaksimal mungkin.

3. Bagi Peneliti Lanjutan

Kepada peneliti lain disarankan agar hasil penelitian ini dapat digunakan sebagai acuan kepustakaan untuk melakukan penelitian dalam variabel yang sama dan memperhatikan kendalakendala yang dialami dalam penelitian ini sebagai bahan pertimbangan untuk perbaikan dan penyempurnaan yang akan dilaksanakan.

\section{DAFTAR RUJUKAN}

Agung, A.A. Gede. 2016. Statistik Dasar Untuk Pendidikan. Yogyakarta: Deepublish
Cahyani, Isah. 2012. Pembelajaran Bahasa Indonesia. Cet. II. Jakarta: Dirjen Pendis Kemenag.

Dantes, Nyoman. 2014. Landasan Pendidikan. Singaraja: Universitas Pendidikan Ganesha\& Graha IImu.

Hakim, Iman Nur. 2014." Pembelajaran Tematik-Integratif di SD/MI dalam Kurikulum 2013". Insania Volume 19, Nomor 1.

Gunawan, Adi W. 2012. Genius Learning Strategy:Petunjuk Praktis Untuk Menerapkan Accelerated Learning. Cet. V. Jakarta: Gramedia Pustaka Utama.

Margunayasa, I Gede, dkk. 2014. Pembelajaran Terpadu Konsep dan Penerapannya. Yogyakarta: Graha IImu.

Maryati, dkk. 2019. "A content analysis study of scientific approach and authentic assessment in the textbook of Curriculum 2013". Jurnal Prima Edukasia. Volume 7. Nomor 2. 128-138.

Millah, Dliyaul \& Syah, M. Noor Sulaiman. "Implementasi Pembelajaran Tematik Integratif di Kelas I Sekolah Dasar Negeri 2 Barongan Kudus". Jurnal Elementary. Volume 5 No.2.

Milez, M.B. dan Huberman, A.M. 1992. Analisis Data Kualitatif.Penerjemah Tjetjep Rohendi. Jakarta: UI- Press.

Najmi, Hayatun, dkk. 2020. "Efektivitas Media Pembelajaran Melalui Model Discovery Learning terhadap Minat dan Hasil Belajar Peserta Didik SDN 193 Pekanbaru. Instructional Development Journal (IDJ). Volume: 3 Nomor: 1.

Rusman. 2016. Pembelajaran Tematik Terpadu:Teori, Praktik dan Penilaian. Jakarta:Rajawali Pers.

Rhosalia, Lulu Anggi. 2017. "Pendekatan Saintifik (Scientific Approach) Dalam Pembelajaran Tematik Terpadu Kurikulum 2013 Versi 2016" . JTIEE, Volume 1 No.1.

Sari, Novika Auliyana. 2018. “ Penerapan Pembelajaran Tematik Terpadu di Sekolah Dasar" . Jurnal Pendidikan. Volume 3, Nomor 12. 
Sundayana, Wachyu. 2014. Pembelajaran Berbasis Tema. Panduan Guru dalam Mengembangkan Pembelajaran Terpadu. Jakarta: Erlangga.

Sugiyono. 2011. Metode Penelitian Kuantitatif Kualitatif dan $R \& D$. Bandung: Alfabeta.

Permatasari, Eka, dkk. 2019. "Analisis Pelaksanaan Pembelajaran Tematik Integratif Dengan Pendekatan Saintifik Pada Siswa Kelas II Dan V Di SDN I Bolorejo Tahun Pelajaran 2017/2018. Jurnal Pendidikan dan Pembelajaran Anak Sekolah Dasar. Volume 4. No. 02.

Widiastuti, Agnesia Maya Kurnia, dkk. 2019. "Keefektivan Pembelajaran Tematik Berbasis Lingkungan dengan Pembelajaran Tematik Buku Guru dan Siswa Terhadap Hasil Belajar Siswa Kelas 4 SD Gugus Gedong Songo. Jurnal Efektor. Volume 6 Nomor 1 